\title{
Prospective study of fetal heart rate and rhythm patterns
}

\author{
D P SOUTHALL, JEAN RICHARDS, ROSE-ANN HARDWICK, E A SHINEBOURNE, \\ G L D GIBBENS, H THELWALL-JONES, M DE SWIET, AND P G B JOHNSTON
}

Department of Paediatrics, Brompton Hospital, and Cardiothoracic Institute, London, and Department of Obstetrics, Dorset County Hospital, Dorchester

SUMMARY The fetal heart beat, detected by ultrasound, was recorded for five minutes from 934 antenatal women-266 at 30 to 35 weeks' gestation and 718 at 36 to 41 weeks. Episodes of bradycardia $<100 /$ minute ranging from 5-30 seconds' duration occurred in $3(1.1 \%)$ of the former and in $9(1.3 \%)$ of the latter group. Tachycardia $>180$ /minute ranging from 30-90 seconds' duration oscurred in $1(0.4 \%)$ of the former and in $4(0.6 \%)$ of the latter. Premature beats were not detected between 30 and 35 weeks, but occurred in $12(1.7 \%)$ of 720 at 36 to 41 weeks' gestation. 50 subjects were monitored at both 30 to 35 weeks and 36 to 41 weeks' gestation and in one woman premature beats were present in the latter but not in the former recording. The incidence $(1.7 \%)$ of premature beats in the fetus at 36 to 41 weeks' gestation was similar to that in the healthy neonate $(0.8 \%)$. Recordings of arrhythmias or rates outside the range 100-180/minute were replayed through a standard antepartum fetal heart rate monitor. The monitor failed to detect premature beats, 2 of 4 episodes of tachycardia $>180 /$ minute, and 9 of 12 episodes of bradycardia $<100 /$ minute, stressing its unreliability for detecting rapidly changing rates.

Disorders of cardiac rhythm and conduction have been shown by standard electrocardiograms (ECG) in $1 \%$ of a population of over 3000 newborn infants. $^{1-3}$ 24-hour ECGs also show a wide variation in normal heart rates and rhythms at this age. ${ }^{4}$ Although there are many reports of fetal arrhythmias-for example, Silber and Durnin, ${ }^{5}$ Hedvall, ${ }^{6}$ Eibschitz et al. ${ }^{7}$ and Armstrong et al. ${ }^{8}$ - the incidence of these disorders in a healthy fetal population is unknown. We have therefore investigated the incidence of fetal heart rate or rhythm disorders in 934 antenatal patients; none had any complication of pregnancy at the time of recording. The findings were compared with those in the healthy newborn infant.

\section{Patients and methods}

Between 1 June 1977 and June 30 1978, 5-minute Doppler recordings of the fetal heart beat were taken from 934 women attending an antenatal clinic in west Dorset. 266 were monitored at 30 to 35 weeks' gestation and 718 were monitored at 36 to 41 weeks' gestation; 50 of them were monitored at both times. Women with complications of pregnancy requiring admission to hospital were excluded. Six mothcrs had twin pregnancies without other complications.

Recordings were performed using an undirectional, single crystal ultrasound detector (Sonic Aid) with a direct connection to a high fidelity cassette recorder (Sony TC 207). Recordings were taken from mothers in the supine position and therefore the possible effects of superior vena caval compression would not have been avoided. Braxton Hicks's contractions were not monitored. The maternal pulse rate was measured during each recording to ensure that the signal received was not from a maternal vessel. Episodes of tachycardia, bradycardia, or rhythm disturbance detected by listening to the tape recordings were replayed on to paper using a fibreoptic recorder (Medilec) from which highest and lowest rates were measured over nine beats. Three subjects with premature beats, 1 with tachycardia $>180$ /minute, and 4 with episodes of bradycardia $<100 /$ minute on the antepartum recordings were monitored continuously during labour with a scalp electrode and fetal ECG monitoring system (Hewlett Packard). An electrical connection allowed the fetal ECG to be recorded continuously on to a 24-hour 
ECG recorder (Oxford Medical Systems). Immediately after birth, 24-hour ECG recordings were taken from 8 subjects with premature beats and 7 with episodes of bradycardia $<100 /$ minute before labour.

The intralabour and postnatal ECG tapes were analysed directly using a system designed to detect heart rate and rhythm disorders from present R-R interval measurements (Oxford Medical Systems).
The recorder and analyser incorporated a Synclock system which, by providing and processing a reference time signal, ensured that possible variations in tape speed did not produce artefactual rhythm and rate patterns.

Finally, Doppler tape recordings of arrhythmias and heart rates outside the range 100-180/minute were replayed through a standard fetal heart rate monitoring system.

Table 1 Number of subjects with rhythm disturbances or rates outside the range 100-180 min on a 5-minute Doppler recording of the fetal heart

\begin{tabular}{|c|c|c|c|c|c|c|}
\hline \multirow[t]{3}{*}{ Number of weeks' gestation } & \multicolumn{4}{|c|}{ No of subjects with episodes } & \multicolumn{2}{|c|}{$\begin{array}{l}\text { No of subjects with } \\
\text { premature beats }\end{array}$} \\
\hline & \multicolumn{2}{|c|}{ Of bradycardia $<100 / \mathrm{min}$} & \multicolumn{2}{|c|}{ Of tachycardia $>18 \mathrm{~J} / \mathrm{min}$} & \multirow[t]{2}{*}{ No } & \multirow[t]{2}{*}{$(\%)$} \\
\hline & No & $(\%)$ & No & $(\%)$ & & \\
\hline $\begin{array}{l}30-35(n=269) \\
36-41(n=721)\end{array}$ & $\begin{array}{l}3 \\
9\end{array}$ & $\begin{array}{l}(1 \cdot 1) \\
(1 \cdot 3)\end{array}$ & $\begin{array}{l}1 \\
4\end{array}$ & $\begin{array}{l}(0.4) \\
(0.6)\end{array}$ & $\begin{array}{r}0 \\
12\end{array}$ & $\begin{array}{l}(0) \\
(1 \cdot 7)\end{array}$ \\
\hline
\end{tabular}

Table 2 Details of the 12 subjects with premature beats

\begin{tabular}{|c|c|c|c|c|c|}
\hline $\begin{array}{l}\text { Gestation at } \\
\text { recording } \\
\text { (weeks) }\end{array}$ & $\begin{array}{l}\text { No of premature } \\
\text { beats in } 5 \text { min }\end{array}$ & $E C G$ in labour & $\begin{array}{l}\text { Postnatal 24-hour } \\
\text { ECG }\end{array}$ & Mode of delivery & $\begin{array}{l}\text { Apgar score at } \\
I \text { min }\end{array}$ \\
\hline $\begin{array}{l}36 \\
36 \\
32,36 \\
36 \\
36 \\
36 \\
37 \\
37 \\
37 \\
37 \\
39 \\
39\end{array}$ & $\begin{array}{l}8 \\
16 \\
0,20 \\
20 \\
56 \\
67 \\
3 \\
13 \\
26 \\
44 \\
3 \\
102\end{array}$ & $\begin{array}{l}\overline{-} \\
\text { PB not detected } \\
177 \text { APB/h } \\
- \\
\overline{17} \text { VPB/h (Fig. 1) } \\
- \\
- \\
- \\
-\end{array}$ & $\begin{array}{l}\text { PB not detected } \\
13 \mathrm{APB} / \mathrm{h} \\
\mathrm{PB} \text { not detected } \\
116 \mathrm{APB} / \mathrm{h} \\
\text { PB not detected } \\
-\mathrm{vPB} / \mathrm{h} \text { (Fig. 1) } \\
20 \mathrm{VPB} / \mathrm{h} \\
290 \mathrm{APB} / \mathrm{h} \\
- \\
-\end{array}$ & $\begin{array}{l}\text { Spontaneous vertex } \\
\text { Spontaneous vertex } \\
\text { Spontaneous vertex } \\
\text { Spontaneous vertex } \\
\text { Spontaneous vertex } \\
\text { Spontaneous vertex } \\
\text { Forceps for delay } \\
\text { Spontaneous vertex } \\
\text { Spontaneous vertex } \\
\text { Spontaneous vertex } \\
\text { Forceps for delay } \\
\text { LSCS for delay and } \\
\text { irregular fetal heart rate }\end{array}$ & $\begin{array}{l}9 \\
8 \\
8 \\
6 \\
8 \\
7 \\
9 \\
8 \\
7 \\
9 \\
6\end{array}$ \\
\hline
\end{tabular}

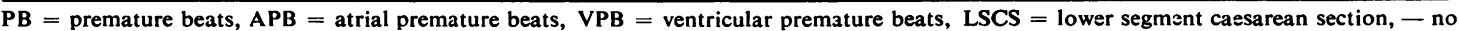
recording.

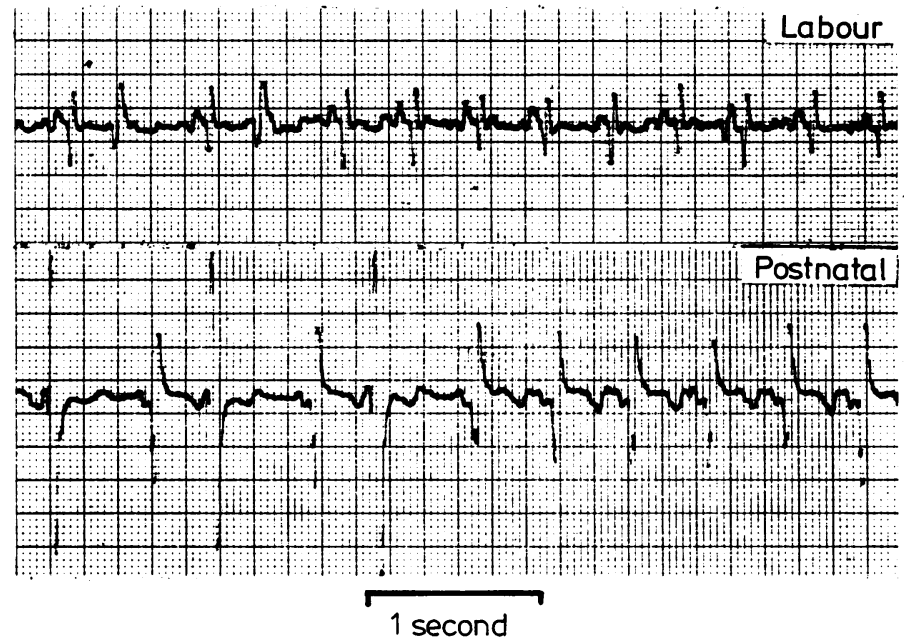

Fig. 1 Upper panel shows a tape recording of the ECG recorded during labour using a scalp electrode and cardiotocograph, from a fetus who had had premature beats on the sonic aid recording at 37 weeks' gestation. Multiple premature beats (17/hour) are present and are also shown in the lower panel (20/hour); a section of 24-hour ECG recording taken postnatally from the same subject. The lack of preceeding $P$ waves, bizarre $Q R S$ configuration, and complete compensatory pause suggests a ventricular origin. The Apgar score at 1 minute was 9. 
Results

The numbers of subjects with rhythm disturbances, episodes of bradycardia $<100 /$ minute, and tachycardia $>180 /$ minute detected by 5-minute Doppler recordings are shown in Table 1 . Of the 8 subjects with premature beats before labour studied by 24-hour ECG recordings after birth, premature beats were present in 5 ; these were supraventricular in origin in 3 and ventricular in 2 (Fig. 1 and Table 2).

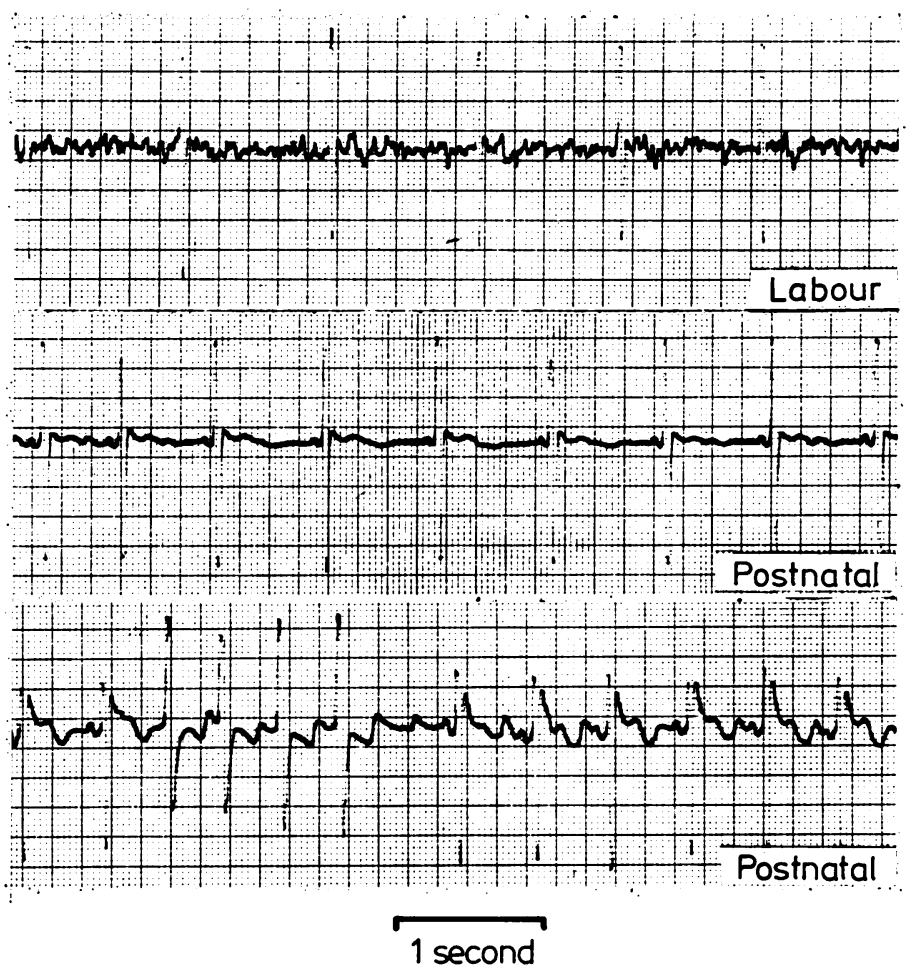

Fig. 2 Top panel is a section of ECG recorded from a fetus during labour who had had episodes of bradycardia down to 53/minute on the sonic aid recording at 37 weeks' gestation. Type II dips were noted on the cardiotocograph printout and the ECG shows a probable junctional escape rhythm of 57/minute. Lower two panels show sections of postnatal 24-hour ECG recordings from the same subject, illustrating a probable junctional escape rhythm of $78 /$ minute (the PR interval is too short to represent a sinus bradycardia) and a short episode of probable supraventricular tachycardia (170/minute). The Apgar score at 1 minute was 8.

Table 3 Details of 12 of 940 subjects with episodes of bradycardia less than 100/min before labour

\begin{tabular}{|c|c|c|c|c|c|c|}
\hline $\begin{array}{l}\text { Gestation at } \\
\text { recording } \\
\text { (weeks) }\end{array}$ & $\begin{array}{l}\text { Lowest } \\
\text { rate/min }\end{array}$ & $\begin{array}{l}\text { Duration of } \\
\text { bradycardia } \\
(s)\end{array}$ & $\begin{array}{l}\text { ECG in labour } \\
\text { (lowest rate over } \\
9 \text { beats) }\end{array}$ & $\begin{array}{l}\text { Postnatal 24-h } \\
\text { ECG (lowest rate } \\
\text { over } 9 \text { beats) }\end{array}$ & $\begin{array}{l}\text { Complications of labour } \\
\text { and mode of delivery }\end{array}$ & $\begin{array}{l}\text { Apgar score } \\
\text { at } 1 \mathrm{~min}\end{array}$ \\
\hline 30,36 & 70 & 5 & - & 一 & $\begin{array}{l}\text { Type I and II dips }(8 \mathrm{~cm} \ddagger) \\
\text { Forceps (fetal distress) }\end{array}$ & 9 \\
\hline $\begin{array}{l}32 \\
34\end{array}$ & $\begin{array}{l}73 \\
80\end{array}$ & $\begin{array}{l}10 \\
12\end{array}$ & 二 & $\underline{75}$ & $\begin{array}{l}\text { Spontaneous vertex } \\
\text { Spontaneous vertex }\end{array}$ & $\begin{array}{l}9 \\
8\end{array}$ \\
\hline 36 & 67 & 30 & 84 & 66 & $\begin{array}{l}\text { Type I dips (5 cm } \ddagger) \text {. } \\
\text { Forceps (breech) }\end{array}$ & 6 \\
\hline 32,36 & 100,78 & 5 & - & - & Forceps (delay) & 9 \\
\hline 37 & 35 & 25 & - & 90 & $\begin{array}{l}\text { Type II dips (4 cmf). } \\
\text { Spontaneous vertex }\end{array}$ & 9 \\
\hline 37 & 53 & 5 & 57 (Fig. 2) & $\begin{array}{l}78 \text { (4 beat SVT) } \\
\text { (Fig. 2) }\end{array}$ & $\begin{array}{l}\text { Type II dips (4 cm } f) \text {. } \\
\text { Spontaneous vertex }\end{array}$ & 8 \\
\hline 37 & 58 & 11 & LSCS & 97 & LSCS $\dagger$ & 9 \\
\hline 37 & 70 & 5 & 65 & 77 & $\begin{array}{l}\text { Type I dips }(6 \mathrm{~cm} \ddagger) \\
\text { Spontaneous vertex }\end{array}$ & 5 \\
\hline 37 & $80^{*}$ & 15 & - & $\begin{array}{l}290 \mathrm{APB} / \mathrm{h} \\
67\end{array}$ & $\begin{array}{l}\text { Type I dips ( } 7 \mathrm{~cm} \ddagger) \text {. } \\
\text { Spontaneous vertex }\end{array}$ & 7 \\
\hline $\begin{array}{l}34,38 \\
39\end{array}$ & $\begin{array}{l}100,90 \\
82\end{array}$ & $\begin{array}{r}5 \\
20\end{array}$ & $\overline{64}$ & - & $\begin{array}{l}\text { Spontaneous vertex } \\
\text { Type II dips ( } 7 \mathrm{~cm} \ddagger) . \\
\text { Forceps (fetal distress) }\end{array}$ & $\begin{array}{l}9 \\
8\end{array}$ \\
\hline
\end{tabular}

* Occasional premature beats also detected. $†$ Performed because of episodes of bradycardia detected by ultrasound. $¥$ Extent of cervical dilatation. LSCS = lower segment caesarean section, SVT $=$ supraventricular tachycardia, - no recording. 
Taiole 4 Details of 4 subjects with episodes of tachycardia greater than 180/min before labour

\begin{tabular}{llllll}
\hline $\begin{array}{l}\text { Gestation at } \\
\text { recording (weeks) }\end{array}$ & Rate/min & $\begin{array}{l}\text { Duration of } \\
\text { episode }(s)\end{array}$ & $\begin{array}{l}\text { ECG in labour } \\
\text { (highest and } \\
\text { lowest rates) }\end{array}$ & Mode of delivery & $\begin{array}{c}\text { Apgar scores at } \\
\text { min }\end{array}$ \\
\hline 36 & 200 & 65 & - & Spontaneous vertex & 8 \\
$33 ; 37$ & $190-200 ; 190$ & $46 ; 60$ & - & Spontaneous vertex & 8 \\
37 & 200 & 40 & - & Forceps (delay) & 8 \\
41 & 200 & 90 & Spontaneous vertex & 9 \\
\hline
\end{tabular}

Table 5 Relationship between mode of delivery, episodes of bradycardia less than 100/min, and Apgar score

\begin{tabular}{|c|c|c|c|c|c|}
\hline \multirow[t]{2}{*}{ Mode of delivery } & \multirow[t]{2}{*}{$\begin{array}{l}\text { No of deliveries with recorded } \\
\text { Apgar scores }(n=828)\end{array}$} & \multicolumn{2}{|c|}{$\begin{array}{l}\text { No with episodes of bradycardia } \\
<100 / \text { min antenatally }\end{array}$} & \multicolumn{2}{|c|}{$\begin{array}{l}\text { No without episodes of bradycardia } \\
<100 / \text { min antenatally }\end{array}$} \\
\hline & & $\begin{array}{l}\text { Apgar score } \\
<7\end{array}$ & $\begin{array}{l}\text { Apgar score } \\
\geqslant 7\end{array}$ & $\begin{array}{l}\text { Apgar score } \\
<7\end{array}$ & $\begin{array}{l}\text { Apgar score } \\
\geqslant 7\end{array}$ \\
\hline $\begin{array}{l}\text { Spontaneous } \\
\text { Forceps or vacuum } \\
\text { Lower segment caesa rean } \\
\text { section }\end{array}$ & $\begin{array}{r}661 \\
106 \\
61\end{array}$ & $\begin{array}{l}2 \\
0 \\
0\end{array}$ & $\begin{array}{l}6 \\
3 \\
1\end{array}$ & $\begin{array}{l}75 \\
25 \\
19\end{array}$ & $\begin{array}{r}578 \\
78 \\
41\end{array}$ \\
\hline
\end{tabular}

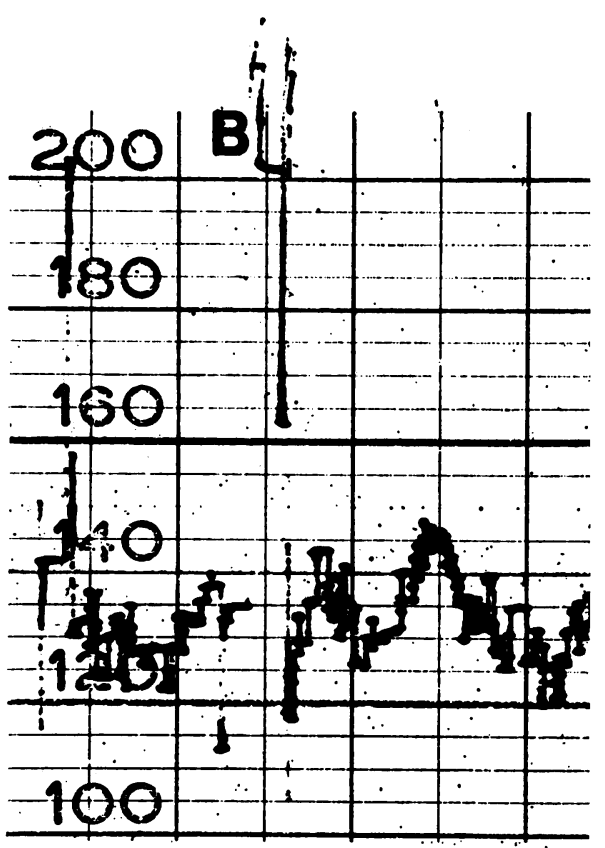

Fig. 3 Printout from an antepartum fetal heart rate monitor obtained by replaying a tape recording of an episode of bradycardia. Heart rate/minute is shown on the vertical axis and paper speed was $1 \mathrm{~cm} /$ minute. $B$ marks the position of the episode of bradycardia to 35/minute. The pen lifts and an artefactual tachycardia is recorded, possibly as a result of an automatic increase in trigger level during the asystole and subsequent detection of signal noise.

It is interesting but not statistically significant $\left(\chi^{2}=3.35 \mathrm{P}<0 \cdot 1\right)$ that premature beats were not detected on recordings taken at 30 to 35 weeks' gestation. All 4 subjects in whom the highest fetal heart rate was greater than 180 /minute (Table 3 ) had a subsequent Apgar score at one minute $>7$.

Of the 12 subjects with bradycardia $<100$ /minute (Fig. 2 and Table 3), 10 had Apgar scores at one minute $\geqslant 7,2$ had Apgar scores $<7$. The relationship between mode of delivery, presence of bradycardia $<100$ /minute before labour, and Apgar score is shown in Table 5. Out of a total of 934 subjects 828 had Apgar scores at one minute recorded in their notes. 816 had rates $>100 /$ minute on the antenatal recordings and of these 119 had Apgar scores $<7$. Two of 12 subjects with bradycardia $<100 /$ minute before labour subsequently had Apgar scores $<7$ at one minute. There was therefore no significant relationship between episodes of bradycardia $<100$ / minute on the antenatal recordings and subsequent low Apgar score.

A standard antepartum fetal heart rate monitor failed to detect all premature beats, 2 of 4 episodes of tachycardia $>180 /$ minute, 4 of 6 episodes of bradycardia between 70 and 100/minute, and 5 of 6 episodes of bradycardia $<70 /$ minute when tape recordings were replayed through this system (Fig. 3).

\section{Discussion}

Disorders of cardiac rhythm and conduction in the neonate have been shown to result in heart failure, ${ }^{9}$ brain damage, ${ }^{10}$ episodes of so-called 'near-miss cot death',10 and in one case sudden infant death.11 Similar disorders may be a cause of some unexplained intrauterine deaths or brain damage. This study was performed to establish the incidence and natural history of fetal arrhythmias.

The frequency $(1.2 \%)$ of premature beats in the 
fetus found in our study was similar to that previously reported $(0.8 \%)$ in a population of healthy neonates ${ }^{1-3}$ in which 26 of 3383 had premature beats on a standard 2-minute ECG. 14 were supraventricular in origin, 11 ventricular, and one subject had both supraventricular and ventricular premature beats. Furthermore, 24-hour ECG recordings on 16 of the 26 neonates with premature beats on the screening ECG showed that 2 also had episodes of supraventricular tachycardia and 3 had episodes of ventricular tachycardia. ${ }^{2-3}$ Arrhythmias other than premature beats-for example, supraventricular tachycardia $^{512-13}$ or atrioventricular block ${ }^{814-15}$ have previously been reported in the fetus and both, especially the former, have been associated with intrauterine heart failure. The incidence of arrhythmias other than premature beats in an apparently healthy population of developing babies requires the study of a larger population using longer recording times. Ultrasound recordings would also fail to detect conduction disorders such as a prolonged QT interval or pre-excitation, unless arrhythmias were also present.

All subjects with premature beats had Apgar scores exceeding 5 (Table 2) conforming with previous reports that have suggested that this arrhythmia in the fetus, without associated tachyarrhythmias, is benign. ${ }^{15-17}$

Episodes of bradycardia $<100 /$ minute and tachycardia $>180 /$ minute have been documented in $1.5 \%$ of apparently healthy developing babies during 5-minute recordings of the fetal heart beat. Bolte and Berendes ${ }^{12}$ using 3- to 5-minute recordings of the fetal ECG from the abdominal surface showed a similar frequency $(2.8 \%)$ of such heart rate changes but they included many mothers with complications of pregnancy. Declarations of the fetal heart rate in labour, in response to a contraction (type II dips), have been suggested as evidence of fetal hypoxaemia, ${ }^{18}$ and have been correlated with poor fetal outcome ${ }^{19}$ and fetal acid-base disturbance. ${ }^{20}$ Similar declarations of the fetal heart rate before labour have also been correlated with intrauterine death or with a poor fetal outcome. ${ }^{21}$ The present study however, suggests that some decelerations before labour may be physiological and care must be taken not to imply abnormality to normal variability. It was interesting to notice in this study that neither an episode of bradycardia nor one of tachycardia before labour was significantly related to subsequent Apgar scores $<7$. We suggest that some fetuses may have an inherent tendency to manifest frequent episodes of bradycardia which do not indicate impaired fetal well-being. Such episodes may also occur subsequently during labour and unnecessary operative intervention follow. Measurement of fetal acid-base balance may help to differentiate between harmful and apparently harmless decelerations. ${ }^{22}$

Traditional antepartum fetal heart rate monitoring systems, using ultrasound or surface abdominal ECG, have problems in avoiding artefact particularly on long-term recordings. Artefact may be due to loss of signal strength during fetal movements or to excessive noise. To overcome these problems many monitors have an inbuilt electronic device to prevent registration of rapidly changing heart rates, on the assumption that such changes are always due to artefact. For this reason, the monitor we used failed to detect premature beats and a large proportion of true episodes of bradycardia from the tape recordings. Present systems used for long-term antepartum monitoring will therefore fail to detect abrupt changes of rate or rhythm. Furthermore, the upper and lower limits of heart rate that can be printed out by these monitors are 200/minute and $60 /$ minute respectively (Fig. 3). Supraventricular and ventricular tachycardias almost always present with heart rates in excess of 200/minute. Sinus tachycardia may exceed 200/minute in the newborn infant but usually for short periods of time. ${ }^{4}$ Currently heart rate monitors cannot differentiate short episodes of sinus tachycardia from tachyarrythmia.

In summary, cardiac arrhythmias and episodes of pronounced bradycardia $<100 /$ minute, or tachycardia $>180 /$ minute occur frequently in the developing baby during normal pregnancy. Assessment of these patterns in the antenatal period should take a knowledge of normality into consideration and the present problems with long-term recording techniques must be overcome.

D P S was supported by a grant from the Board of Governors of the Brompton Hospital, National Heart and Chest Hospital, and J R by the Foundation for the Study of Infant Deaths. The project was supported by a grant from the British Heart Foundation and donations from the League of Friends of Dorchester and Weymouth Hospitals, the Weymouth Lions, Round Table, and League of the Licensed Trade.

\section{References}

1 Southall D P, Vulliamy D G, Davies M J, Anderson R H, Shinebourne E A, Johnson A M. A new look at the neonatal electrocardiogram. $\mathrm{Br}$ Med J 1976; ii: 615-8.

2 Southall D P, Orrell M J, Talbot J F, et al. Study of cardiac arrhythmias and other forms of conduction abnormality in newborn infants. Br Med J 1977; ii: 597-9.

3 Southall D P, Johnson A M, Shinebourne E A. Study of the nature and natural history of disorders of cardiac rhythm and conduction in the apparently healthy infant. In: Godman P, ed. Paediatric cardiology. Proceedings of 
the First World Congress in Paediatric Cardiology, London, June 1980. Edinburgh: Churchill Livingstone, 1980. In press.

4 Southall D P, Richards J, Mitchell P, Brown D J, Johnston P G B, Shinebourne E A. Study of cardiac rhythm in healthy newborn infants. Br Heart $J$ 1980; 43: 14-20.

5 Silber D L, Durnin R E. Intrauterine atrial tachycardia associated with massive edema in a newborn. Am J Dis Child 1969; 117: 722-6.

- Hedvall G. Congenital paroxysmal tachycardia: a report of 3 cases. Acta Paediatr Scand 1973 ; 62: 550-2.

7 Eibschitz I, Abinader E G, Klein A, Sharf M. Intrauterine diagnosis and control of fetal ventricular arrhythmia during labor. Am J Obstet Gynecol 1975; 122: 597-600.

8 Armstrong D H, Murata Y, Martin C B, Jr, Ikenoue T. Antepartum detection of congenital complete fetal heart block. A case report. Am J Obstet Gynecol 1976; 126: 291-2.

9 Schreiner R L, Hurwitz R A, Rosenfeld C R, Miller W. Atrial tachyarrhythmias associated with massive edema in the newborn. J Perinat Med 1978; 6: 274-9.

10 Keeton B R, Southall E, Rutter N, Anderson R H, Shinebourne E A, Southall D P. Cardiac conduction disorders in six infants with 'near-miss' sudden infant deaths. Br Med J 1977; ii: 600-1.

11 Southall D P, Arrowsmith W A, Oakley J R, McEnery G, Anderson R H, Shinebourne E A. Prolonged QT interval and cardiac arrhythmias in two neonates: sudden infant death syndrome in one case. Arch Dis Child 1979; 54: 776-9.

12 Bolte A, Berendes R. Frequenz und Rhythmus der fetalen Herzaktionspotentiale im Verlauf der Graviditat. Geburtshilfe Frauenheilkd 1972; 32: 635-49.

13 Radford D J, Izukawa T, Rowe R D. Congenital paroxysmal atrial tachycardia. Arch Dis Child 1976; 51 : 613-7.
14 Altenburger K M, Jedziniak M, Roper W L, Hernandez J. Congenital complete heart block associated with hydrops fetalis. J Pediatr 1977; 91: 618-20.

15 Komáromy B, Gaál J, Mihály G. Mocsáry P, Pohánka O, Surányi S. Data on the significance of fetal arrhythmia. Am J Obstet Gynecol 1967; 99: 79-85.

${ }^{16}$ Hon E H, Huang H S. The electronic evaluation of fetal heart rate. VII. Premature and missed beats. Obstet Gynecol 1962; 20: 81-90.

17 Kendall B. Abnormal fetal heart rates and rhythms prior to labor. Am J Obstet Gynecol 1967; 99: 71-8.

18 Huch R, Huch A. Continuous measurement of fetal $\mathrm{pH}$ and $\mathrm{PO}_{2}$. In: Beard $\mathrm{R} \mathrm{W}$, Campbell $\mathrm{S}$, eds. The current status of fetal heart rate monitoring and ultrasound in obstetrics. London: Royal College of Gynaecologists, 1977: 71-99.

19 Shelley T, Tipton R H. Dip area. A quantitative measure of fetal heart rate patterns. J Obstet Gynaecol Br Comm 1971: 78: 694-701.

${ }^{20}$ Kubli F W, Hon E H, Khazin A F, Takemura H. Observations on heart rate and $\mathrm{pH}$ in the human fetus during labour. Am J Obstet Gynecol 1969; 104: 1190-206.

21 Emmen L, Huisjes H J, Aarnoudse J G, Visser G H A, Okken A. Antepartum diagnosis of the 'terminal' fetal state by cardiotocography. BrJ Obstet Gynaecol 1975; 82: 353-9.

22 Filshie M. Intrapartum fetal monitoring. Br J Hosp Med 1974 ; 12: 33-46.

Correspondence to Dr D P Southall, Cardiothoracic Institute, Fulham Road, London SW3 6HP.

Received 26 July 1979 